solved. Seed production is achieved in Florida where there are short days without the rigours of an autumn climate.

To the plant physiologist, on the other hand, photo-periodism presents a most baffling problem. When considering a reaction in the plant induced by light, he attempts at first to interpret it in terms of chemistry and therefore expects the 'product law' to hold. The effect should depend on the quantity of light energy received, and so should depend both on the time of exposure and the intensity of light. With the photo-periodic reaction we find no such relationship. It might be thought at first sight that the long-day plants require a greater light-supply for their flower formation than do the short-day ones. But this cannot be the explanation, for with long-day plants an exposure to a 10-hour day can be continued for a period which will give a total light supply much higher than is given by an exposure to a 14-hour day; yet flowering will result in the second case and not in the first. Duration of illumination rather than quantity of light is the important thing, and this is exceedingly difficult to interpret in terms of physiology. In the case of short-day plants there is some reason for believing that it is the corollary of the period of illumination, namely, the period of darkness, to which attention should be directed.

(To be continued.)

\title{
André Marie Ampere, I775-I836
}

\section{By Dr. D. McKie, University College, London}

A NDRE MARIE AMPÈRE was born in Lyons on January 20,1775, and died at Marseilles on June 7, 1836. His early childhood was spent in the country near his birthplace and his first studies were directed by his parents. A childish pastime of carrying out complicated arithmetical calculations with little pebbles was prophetic of his future devotion to mathematical studies, a devotion that was evidenced again when his father, a retired merchant, began to teach him Latin; for the young Ampere quickly showed his great preference for mathematics, whereupon his father wisely allowed natural inclination to take its own course, providing the necessary introductory works from his own small library. But when these had been mastered, more advanced reading was necessary; and it is recorded that, at twelve years of age, Ampere, accompanied by his father, went to ask in his piping boyish voice for the loan of the works of Euler and Bernoulli from the College Library at Lyons. He appears to have mastered these classics also ; and he read widely in the literary, historical, scientific and philosophical authors of his country. In fact, like a recent Lord Chancellor of England, he turned to the current encyclopædia, in his case that of Diderot and d'Alembert, to equip himself with the accumulated knowledge of the ages; and a half-century later he was able to recite from memory whole passages from the famous "Encyclopédie" that expressed the genius of eighteenth century France.

Ampère's extraordinarily rapid intellectual development was, however, interrupted by the tragio death of his father, executed in 1793 as a victim of the Revolution. The shock of this event left Ampère bereft of all his faculties for a whole year, in which he is said to have done nothing but play childishly with heaps of sand and gaze vacantly at the sky, until by a fortunate chance he picked up Rousseau's "Lettres sur la botanique", the reading of which revived his interest and carried him back to his scientific studies. He now began to teach mathematics ; and shortly afterwards, in 1801, he was appointed to the Ecole centrale at Bourg. In 1803 he became professor of mathematics at the Lycée in Lyons. But in $\mathbf{1 8 0 5}$ his increasing reputation carried him to an appointment at the Ecole polytechnique in Paris, where he was appointed professor in 1809. He was elected to the Academy in 1814, and in 1824 he became professor of physics at the Collège de France.

In August 1799 Ampère contracted a happy but short-lived marriage with Mlle. Julie Carron, the daughter of a devout neighbouring family. The family were not over-blessed with this world's goods, but in their company Ampère appears to have found his spiritual ease, possibly through their reflection of his own natural piety, his religion throughout his life being something totally apart from his scientific interests and speculations. The only child of the marriage, a son, Jean Jacques, was born in 1800 and became a professor at the College de France and a member of the Academy. Mme. Ampere died after prolonged illness in 1803, some short time after Ampère had returned home from a separation enforced by his teaching duties elsewhere ; and it is fortunate, having regard to the 
severe consequences of the first, that Ampère was able to withstand this second tragedy of his early years as no more than a great and lasting grief.

Amperre's first scientific contribution, which dealt with the mathematical theory of games of chance, was published at Lyons in 1802. It attracted the attention of Delambre, and thereby led to Ampère's appointment at the Lycée. From then onwards Ampère published numerous memoirs on mathematics, physics and chemistry. But his classical work lay in the field of electro-magnetism, and it is for these researches that he is remembered as the father of electro-dynamics. His work here followed almost immediately on the announcement in July 1820 of the discovery by Oersted ("Experimenta circa Effectum Conflictus Electrici in Acum Magneticam", Copenhagen, 1820) that an electric current affected a magnetic needle, in brief, the discovery of electro-magnetism and the demonstration of the long-suspected connexion between electricity and magnetism. Many physicists turned their attention to this remarkable discovery, but it was Ampere who proved most successful; and in September of the same year he read before the Paris Academy of Sciences the first of a series of papers, setting out his own discoveries in electro-dynamics, including more notably the laws governing the deflection of the magnetic needle with regard to the current and the mutual attractions and repulsions of electric currents.

In 1822 Ampere presented to the Academy his mathematical analysis of these phenomena, confirming his studies in 1827 in his "Mémoire sur la théorie mathématique des phénomènes électrodynamiques uniquement déduite de l'expérience", showing that an electric current is equivalent in its external effects to a magnetic shell, and propounding the theory that magnetism is the result of molecular electric currents. Of this work Arago wrote: "The vast field of physical science perhaps never presented so brilliant a discovery, conceived, verified and completed with such rapidity". And much later Clerk Maxwell said: "The whole, theory and experiment, seems as if it had leaped, full grown and full armed, from the brain of the 'Newton of electricity'. It is perfect in form, and unassailable in accuracy, and it is summed up in a formula from which all the phenomena may be deduced, and which must always remain the cardinal formula of electro-dynamies."

Among other interesting details of Ampère's scientific work, it might be noted that he devised astatic needles, formulated the well-known 'Ampère's Rule' for determining the deflection of a magnet by an electric current, suggested the electric telegraph as an application of Oersted's discovery, published an "Essai" (1834) on the philosophy and classification of the sciences, and expressed, unaware of their earlier publication, ideas similar to those expounded in Avogadro's hypothesis. Moreover, he was opposed to the caloric theory, regarding heat, as well as light, as the result of vibratory motion.

For his epitaph, Ampère chose the words tandem felix (happy at last). In France, the centenary of his death has been marked by the issue of a com. memorative stamp and by an exhibition in his native city of Lyons. In the world of science he is remembered daily, the 'ampere', the practical unit of electric current, perpetuating his memory.

\section{Obituary}

Prof. A. C. Dixon, F.R.S.

DROF. ALFRED CARDEW DIXON, who died suddenly on May 4, at the age of seventy years, at his home in Northwood, Middlesex, was a mathe. matician of great ability and power, with a high reputation, founded, in the first place, on his brilliant Cambridge record, and steadily built up by a lifetime of research on a most unusual variety of mathematical topics.

As a student at Cambridge, Dixon's name, from all accounts, was one to conjure with; and he was perhaps best known to the public as the Senior Wrangler of 1886, who had the reputation of being unbeaten in any examination for which he had ever entered. He was a fellow of Trinity College, Cambridge, a fellow of the Royal Society; and on his retirement, after thirty years' service, from the chair of mathematics at the Queen's University, Belfast, he settled down in Northwood; he was elected president of the London Mathematical Society for the period 193I-33.

In private life, Dixon was as quietly simple and sincere as he was distinguished in public life; and this kindly simplicity and sincerity endeared him exceedingly to all who came much in personal contact with him. He was by persuasion a Methodist, and took a deep and lifelong interest in all the affairs of his church; and he was passionately fond of music and for many years an enthusiastic performer in the Philharmonic Orchestra, Belfast.

In his original work, Dixon contributed to many fields, and to every one something of strength and value. His earliest interests were partly geometrical ; and his researches on plane cubics, the double-six 